\title{
Intrapancreatic MSC transplantation facilitates pancreatic islet regeneration
}

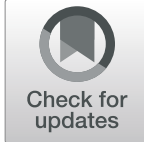

Rahul Khatri, Sebastian Friedrich Petry and Thomas Linn ${ }^{*}$ (1)

\begin{abstract}
Background: Type 1 diabetes mellitus (T1D) is characterized by the autoimmune destruction of the pancreatic $\beta$ cells. The transplantation of mesenchymal stromal/stem cells (MSC) was reported to rescue the damaged pancreatic niche. However, there is an ongoing discussion on whether direct physical contact between MSC and pancreatic islets results in a superior outcome as opposed to indirect effects of soluble factors released from the MSC entrapped in the lung microvasculature after systemic administration. Hence, MSC were studied in direct contact (DC) and indirect contact (IDC) with murine pancreatic $\beta$ cell line MIN6-cells damaged by nitrosourea derivative streptozotocin (STZ) in vitro. Further, the protective and antidiabetic outcome of MSC transplantation was evaluated through the intrapancreatic route (IPR) and intravenous route (IVR) in STZ-induced diabetic NMRI nude mice.

Methods: MSC were investigated in culture with STZ-damaged MIN6-cells, either under direct contact (DC) or separated through a semi-permeable membrane (IDC). Moreover, multiple low doses of STZ were administered to NMRI nude mice for the induction of hyperglycemia. $0.5 \times 10^{6}$ adipose-derived mesenchymal stem cells (ADMSC) were transferred through direct injection into the pancreas (IPR) or the tail vein (IVR), respectively.

Bromodeoxyuridine (BrdU) was injected for the detection of proliferating islet cells in vivo, and real-time polymerase chain reaction (RT-PCR) was employed for the measurement of the expression of growth factor and immunomodulatory genes in the murine pancreas and human MSC. Phosphorylation of AKT and ERK was analyzed with Western blotting.

Results: The administration of MSC through IPR ameliorated hyperglycemia in contrast to IVR, STZ, and nondiabetic control in a 30-day window. IPR resulted in a higher number of replicating islet cells, number of islets, islet area, growth factor (EGF), and balancing of the Th1/Th2 response in vivo. Physical contact also provided a superior protection to MIN6-cells from STZ through the AKT and ERK pathway in vitro in comparison with IDC.
\end{abstract}

Conclusion: Our study suggests that the physical contact between MSC and pancreatic islet cells is required to fully unfold their protective potential.

Keywords: Adipose-derived mesenchymal stem cells, Type 1 diabetes mellitus, Intrapancreatic route, Intravenous route, $\beta$ cell protection

\footnotetext{
* Correspondence: Thomas.Linn@innere.med.uni-giessen.de

Clinical Research Unit, Centre of Internal Medicine, Faculty of Medicine, Justus Liebig University Giessen, Friedrichstrasse. 20/ Aulweg 123, 35392 Giessen, Germany
}

(c) The Author(s). 2021 Open Access This article is licensed under a Creative Commons Attribution 4.0 International License, which permits use, sharing, adaptation, distribution and reproduction in any medium or format, as long as you give appropriate credit to the original author(s) and the source, provide a link to the Creative Commons licence, and indicate if changes were made. The images or other third party material in this article are included in the article's Creative Commons licence, unless indicated otherwise in a credit line to the material. If material is not included in the article's Creative Commons licence and your intended use is not permitted by statutory regulation or exceeds the permitted use, you will need to obtain permission directly from the copyright holder. To view a copy of this licence, visit http://creativecommons.org/licenses/by/4.0/. The Creative Commons Public Domain Dedication waiver (http://creativecommons.org/publicdomain/zero/1.0/) applies to the data made available in this article, unless otherwise stated in a credit line to the data. 


\section{Background}

Type 1 diabetes mellitus (T1D) is an autoimmune disorder manifested by a chronic hyperglycemic state due to insulin deficiency [1]. The worldwide diabetes mellitus prevalence is predicted to grow from 415 million (2015) to 642 million (2040), which poses an enormous economic and financial burden [2]. Out of which, T1D contributes to $10-15 \%$ especially children below the age of 2 years [3]. Since uncontrolled blood glucose will lead to both macrovascular and microvascular diabetic complications [4], patients are required to maintain their blood glucose level within a narrow range. However, multiple daily injections of exogenous insulin as the standard therapeutic practice entail recurrent hypoglycemic episodes and restricted life quality.

In recent years, MSC-based remedies have emerged as a persuasive source of T1D treatment including the prevention of its secondary complications and $\beta$ cell substitution [5-7]. MSC are non-hematopoietic, fibroblastlike, multipotent stromal cells which could be gleaned efficiently from a wide variety of tissues and rapidly undergo mesodermal lineage differentiation, for instance, cardiomyocytes, myoblasts, adipocytes, chondrocytes, and $\beta$ cell-like cells [8-11]. MSC T1D therapy was reported to ameliorate hyperglycemia, stimulate pancreatic islet repair mechanisms by secreting cytokines and growth factors, and immunomodulate the host's immune system $[12,13]$.

MSC administered through a systemic route are exposed to lung microvasculature entrapment, the sequel in restricted access to the target organ, and display inferior protective potential [14-17]. In a randomized trial with T1D patients, a single intravenous injection prevented $\mathrm{C}$-peptide loss up to 1 year but failed to regulate blood glucose levels without an additional insulin application [14], while the intravenous infusion of human umbilical cord blood-derived MSC and the intrapancreatic injection were nearly equivalent in balancing the blood glucose level in diabetic mice [15]. However, in some reports, the intrapancreatic route of MSC application resulted in a superior curative effect on blood glucose concentrations compared to the intravenous administration [16-18]. MSC administered through the intrapancreatic route reversed the hyperglycemic state in $42 \%$ and via the intrasplenic route in $70 \%$ of diabetic recipient mice [19]. As possible underlying mechanisms, Murai et al. demonstrated a reduced number of activated macrophages in the murine pancreas after intrapancreatic injection of human BM-MSC and confirmed the intrapancreatic supremacy over intravenous injection in T1D [20].

Taken together, both routes of administration seem to exert restorative effects on damaged $\beta$ cells, but with differentially activated patterns [21-24]. As a major difference, the intrapancreatic route (IPR) of transplantation allows the physical contact of MSC with pancreatic $\beta$ cells, while the intravenous route (IVR) leads to their off-site accumulation and only indirect effects on the pancreas. However, it is still uncertain whether the physical contact between MSC and pancreatic $\beta$ cells is vital for a better outcome, or a distant effect is sufficient for MSC-based therapies aiming for $\beta$ cell preservation. Moreover, the source of the MSC from different human tissues might influence the therapeutic efficacy. Therefore, we utilized the immortalized bone marrow-derived hTERT-MSC line to study the interaction of MSC with $\beta$ cells in co-culture system. In addition, primary MSC from adipose tissue were applied for the in vivo transfer into diabetic NMRI nude mice via IVR and IPR routes. Our study provides evidence for a superior antidiabetic effect of locally administered MSC over the systemic route in STZ-induced diabetic NMRI nude mice, which might be beneficial for future therapies focusing on $\beta$ cell preservation and restoration.

\section{Material and methods \\ Cell culture \\ MIN6-cells}

MIN6-cells are defined as a $\beta$ cell line that originated from mouse insulinoma, 6th subclone. MIN6-cells were cultivated and maintained in DMEM (Gibco, Germany) with $50 \mu \mathrm{M} \beta$-mercaptoethanol (Sigma, Germany), 20\% FBS (Biowest, USA), and $1 \%$ penicillin-streptomycin in an incubator with $5 \% \mathrm{CO}_{2}$ at $37{ }^{\circ} \mathrm{C}$.

\section{hTERT-MSC}

hTERT-MSC were seeded with $5 \times 10^{4}$ cells $/ \mathrm{cm}^{2}$ in MEM media (Gibco, Germany) with 1\% L-glutamine (Invitrogen, Germany), 10\% FBS (Biowest, USA), and 1\% penicillin-streptomycin (Invitrogen, Germany) and maintained at $37^{\circ} \mathrm{C}$ in an incubator. After attaining $70-80 \%$ confluency, hTERT-MSC were employed for further experiments.

\section{Adipose-derived mesenchymal stem cells (ADMSC)}

ADMSC were isolated as detailed previously [25]. Briefly, ADMSC were seeded with $5 \times 10^{4}$ cells $/ \mathrm{cm}^{2}$ in T-175 flask (Corning, USA) in DMEM media (D5671, Sigma) with 20\% FBS (Biowest, USA), 1\% non-essential amino acid (NEAA, Gibco, Germany), 1\% L-glutamine (Invitrogen, Germany), and 1\% penicillin-streptomycin (Invitrogen, Germany) with $5 \% \mathrm{CO}_{2}$ at $37{ }^{\circ} \mathrm{C}$ in an incubator. For the transplantation, cells were detached with trypsin-EDTA. The enzymatic reaction was halted with 20\% FBS containing DMEM media. Cells were counted with trypan blue in a Neubauer chamber, and $0.5 \times 10^{6} /$ $100 \mu \mathrm{L}$ was considered for the transplantation. 


\section{Direct contact (DC) and indirect contact (IDC) co-culture system \\ Viability}

Five thousand MIN6-cells/well were seeded overnight in a 96-well plate for DC. MIN6-cells were incubated with STZ (0.5 mM, $1.0 \mathrm{mM}$, or $2.0 \mathrm{mM})$ for another $24 \mathrm{~h}$ to induce injury. Further, 2000 hTERT-MSC were added to attain physical contact for $24 \mathrm{~h}$. In the case of IDC, 5000 MIN6-cells/well were subjected to HTS Transwell ${ }^{\text {TM }}$ 96Well Permeable Support System, Corning ${ }^{\mathrm{TM}}$ overnight, and incubated for $24 \mathrm{~h}$ with STZ $(0.5 \mathrm{mM}, 1.0 \mathrm{mM}$, or $2.0 \mathrm{mM}$ ). The next day, 2000 hTERT-MSC were grown on a transwell with pore size $0.4 \mu \mathrm{m}$ for $24 \mathrm{~h}$. Ninety-sixwell plate from DC and IDC was continued with MTT $(50 \mu \mathrm{L}$ from the stock solution of $2 \mathrm{mg} / \mathrm{mL}$, Sigma, Germany) and maintained in dark for $4 \mathrm{~h}$ at $37^{\circ} \mathrm{C}$. Further, $200 \mu \mathrm{L}$ DMSO was added and incubated for another $1 \mathrm{~h}$ at RT. Mithras LB 940 Multimode Microplate Reader was adopted to capture the absorbance at 590 $\mathrm{nm}$ and $620 \mathrm{~nm}$ (reference filter).

\section{Migration assay}

In 24-well plate, $0.3 \times 10^{6} \mathrm{MIN6}$-cells were grown overnight and challenged with STZ $(0.5 \mathrm{mM}, 1.0 \mathrm{mM}$, or 2.0 $\mathrm{mM}$ ) for $24 \mathrm{~h}$. On the following day, $8-\mu \mathrm{m}$ pore size inserts including $2 \times 10^{4}$ hTERT-MSC were added to each well. After $24 \mathrm{~h}$, inserts were taken, and the inner portion was cleaned with cotton. The membrane was washed and developed with the FDA for $15 \mathrm{~min}$ at $37^{\circ} \mathrm{C}$. Migrated hTERT-MSC were assessed after capturing pictures and analyzing them with Image software (National Institutes of Health, USA).

\section{Induction of diabetes and transfer of ADMSC to mice}

NMRI nu/nu athymic mice with the age of 10 to 12 weeks were acquired from Janvier (France). Mice were retained at a 12:12-h cycle (light to dark) with $24 \pm$ $2{ }^{\circ} \mathrm{C}$ temperature and equipped with standard food (1324 TFP, ad libitum, Altromin, Germany) and water. All procedures were pursued in conformity with the German Animal Welfare Law and institutional guidelines (code 31/2017).

In this experiment, four groups were established: control (sham control; non-diabetic and non-transplanted mice), STZ, IVR, and IPR. Three groups (STZ, IVR, and IPR) were injected with multiple low doses of streptozotocin (STZ) intraperitoneally (Fig. 3a). Forty milligrams per kilogram body weight of STZ was administered for three successive days culminating in an overall dose of $120 \mathrm{mg} / \mathrm{kg}$ body weight. Blood glucose was tested with a hand-held glucose meter (One Touch $^{\circledR}$ Ultra $^{\circledR} 2$, LifeScan) by pin-pricking the tail vein.

Mice with a blood glucose level above $11.1 \mathrm{mmol} / \mathrm{L}$ were considered for transplantation. They were anesthetized with xylazine $(20 \mathrm{mg} / \mathrm{kg}$ body weight; Ceva, Germany) and ketamine (100 mg/kg body weight; Medistar, Germany). A middle line incision was accomplished to uncover the pancreas. In the IPR group, $0.5 \times 10^{6} /$ $100 \mu \mathrm{L}$ ADMSC were injected gently into the intermediate part of the pancreas (3-5 mm deep) accompanied by the closure of the abdominal skins with synthetic absorbable suture (Vicryl suture 5-0, Ethicon, USA) within 10-15 min. The IVR group received ADMSC $\left(0.5 \times 10^{6} /\right.$ $100 \mu \mathrm{L})$ through a tail vein. At the end of the experiment, BrdU (100 mg/kg body weight) was administered for three consecutive days before the organ retrieval as shown in Fig. 3a.

\section{RT-PCR}

Total RNA from the mouse pancreas was extracted with peqGOLD TrifastTM reagent (peqlab, Germany) and pursued with RNeasy Mini Kit (Qiagen). However, RNeasy Micro Kit (Qiagen) was employed for the hTERT-MSC and MIN6-cell RNA isolation as per the manufacture's instruction. c-DNA was transcribed with $1 \mu \mathrm{g}$ RNA by utilizing the SuperScript III Reverse Transcriptase kit (Invitrogen, Germany). RT-PCR (StepOnePlus, Applied Biosystems) was accomplished with SYBR Green Supermix (Bio-Rad Laboratory, Germany), cDNA template, and primers $(20 \mathrm{pM})$. PCR reaction was carried out with initial denaturation at $95^{\circ} \mathrm{C}$ for $10 \mathrm{~min}$, denaturation $\left(95^{\circ} \mathrm{C}, 15 \mathrm{~s}\right)$ for 40 cycles, annealing at $60{ }^{\circ} \mathrm{C}$ for $30 \mathrm{~min}$, extension $\left(60^{\circ} \mathrm{C}, 1 \mathrm{~min}\right)$, and melting curve. For the primer list, refer to Table 1.

\section{Western blot}

MIN6-cell lysates were produced with 1X RIPA buffer (200 $\mu \mathrm{L}$; Cell Signalling Technology, Germany) possessing protease inhibitor (Thermo Scientific, Germany). Lysates were vortexed and incubated for $20 \mathrm{~min}$ on ice. After centrifugation $\left(12,000 \mathrm{rpm}\right.$ at $4{ }^{\circ} \mathrm{C}$ for $\left.20 \mathrm{~min}\right)$, the protein was collected and quantified with Bio-Rad Protein Assay (Bio-Rad, Germany). Sodium dodecyl sulfatepolyacrylamide gel electrophoresis (SDS-PAGE) was implemented, and proteins were transferred on activated polyvinylidene fluoride (PVDF; EMD) followed by blocking with $5 \%$ milk powder (Sigma, Germany). The membrane was exposed to primary antibodies: AKT (1:1000, Rabbit AKT Antibody, Cell signaling), p-AKT (1:1000, Rabbit Phospho-AKT; Ser473, Cell signaling), ERK (1: 1000, Rabbit ERK Antibody, Cell signaling), and p-ERK (1:1000, Rabbit Phospho-p44/42 MAPK; Erk1/2, Cell signaling) overnight at $4{ }^{\circ} \mathrm{C}$. The membrane was rinsed with TBST thrice and incubated with Polyclonal Goat AntiRabbit Immunoglobulins/HRP secondary antibody (1: 3000; Dako, Germany) and pursued with enhanced chemiluminescence (ECL) developing system. 
Table 1 RT-PCR primers

\begin{tabular}{|c|c|c|}
\hline Primer & Forward primer & Reverse primer \\
\hline m EGF & 5'-TCTCGGATTGACC CAGAT-3' & 5'-CCCAGACACCTTCCTCTCT-3' \\
\hline m Ins1 & 5'-TATAAAGCTGGTGGGCATCC-3' & 5'-GGGACCACAAAGATGCTG TT-3' \\
\hline $\mathrm{m}$ Ins2 & 5'-GGCTTCTTCTACACACCCATGT-3' & 5'-AAGGTCTGAAGGTCACCTGCTC-3' \\
\hline m FoxO1 & 5'-TTCAATTCGCCACAATCTG TCC-3' & 5'-GGGTGATTTTCCGCTCTTGC-3' \\
\hline m TNF-a & 5'-CATCTTCTCAAAATTCGAGTGACAA-3' & 5'-TGGGAGTAGACAAGG TACAACCC-3' \\
\hline m SDF-1 & 5'-AACCAGTCAGCCTGAGCTAC-3' & 5'-GGGTCAATGCACACTTGTCTG-3' \\
\hline m BCL2 & 5'-ATGCCTTTGTGGAACTATATGGC-3' & 5'-GGTATGCACCCAGAGTGATGC-3' \\
\hline m BAX & 5'-TGAAGACAGGGGCCTTITTG-3' & 5'-AATTCGCCGGAGACACTCG-3' \\
\hline$m I L-1 \beta$ & 5'-AGGTCGCTCAGGGTCACAAG-3' & 5'-GTGCTGCCTAATGTCCCCTTGAATC-3' \\
\hline m IL-10 & 5'-TAAGGCTGGCCACACTTGAG-3' & 5'-GTTTCAGGGATGAAGCGGC-3' \\
\hline m ERK & 5'-TCAGTTTGTCCCCTTCCATTG-3' & 5'-TCCACTCCCACAATGCACAC-3' \\
\hline m DLK1 & 5'-AGTGCGAAACCTGGGTGTC-3' & 5'-GCCTCCTTGTTGAAAGTGGTCA-3' \\
\hline m RPL32 & 5'-GGAGAAGGTTCAAGGGCCAG-3' & 5'-GCGTTGGG ATTGGTGACTCT-3' \\
\hline h CXCR4 & 5'-GACTGGCATAGTCGGCAATG-3' & 5'-AGAAGGGGAGTGTGATGACAAA-3 \\
\hline h TIMP1 & 5'-TTGTGGACGGACCAGCTCCT-3' & 5'-GGTGGACACTGTGCAGGCTT-3' \\
\hline h IDO1 & 5'-AGCTGCGCTGATAGACATCC-3' & 5'-GGCGCTGTGACTTGTGGTCT-3' \\
\hline h VEGF & 5'-CTACCTCCACCATGCCAAGT-3' & 5'-AGCTGCGCTGATAGACATCC-3' \\
\hline h RPL13 & 5'-CCTGGAGGAGAAGAGGAAAGAGA-3' & 5'-TTGAGGACCTCTGTGTATTTGTCAA-3' \\
\hline
\end{tabular}

\section{Immunohistochemistry}

After 30 days, the pancreases were retrieved from all four groups and fixed with $4 \%$ paraformaldehyde for $6 \mathrm{~h}$ followed by washing and paraffin embedding. Pancreatic sections with 5- to 7- $\mu \mathrm{m}$ thickness were cut and processed for antigen retrieval. Sections were exposed to $\mathrm{NaOH}$, processed further for blocking with goat serum (1\%) at RT for $20 \mathrm{~min}$, stained with primary antibody: polyclonal guinea pig anti-insulin, DAKO (1:100 from the stock of $26.1 \mathrm{~g} / \mathrm{L}$ ) overnight at $4{ }^{\circ} \mathrm{C}$, and afterward subjected to secondary antibodies: AP-conjugated affinity-purified anti-guinea pig from Rockland, Germany (1:40 from the stock of $1 \mathrm{mg} / \mathrm{mL}$ ) for $1 \mathrm{~h}$ at RT. Insulin was developed with a vector blue substrate kit (Vector Laboratory, Germany). Further, a rodent blocker (BIOCARE MEDICAL, Germany) was administered for $30 \mathrm{~min}$ before the treatment with an anti-BrdU antibody (1:100 from the stock of $262 \mathrm{mg} / \mathrm{mL}$, DAKO, Germany) at $4{ }^{\circ} \mathrm{C}$ overnight. A mouse on mouse HRP polymer (BioCare Medical, Germany) was employed, and the BrdU-positive brown color was developed with ImmPACT $^{\mathrm{rm}}$ AMEC Red Substrate. A light microscope (Leica microsystem, ICC50 HD) was utilized to capture the pictures. Morphometric analyses were standardized using blinded examiner readings.

\section{ELISA}

After 30 days, blood serum and pancreas were isolated from all the four groups. The pancreas was mechanically grinded and exposed to acid ethanol as reported earlier
$[26,27]$. Blood was centrifuged at $3000 \mathrm{rpm}$ for $10 \mathrm{~min}$ at $4{ }^{\circ} \mathrm{C}$, and serum was collected. A mouse Insulin ELISA kit (DRG Instruments $\mathrm{GmbH}$, Germany) was used to measure the insulin content.

\section{Statistical analysis}

GraphPad Prism 8 (GraphPad, USA) was employed for statistics. Data were shown as a mean \pm SEM. Multiple $t$ test or two-way ANOVA was adopted with post hoc analysis depending on the experiments unless otherwise stated. For the survival curve, the log-rank (Mantel-Cox) test was applied. Significant statistics are illustrated by ${ }^{*} p \leq 0.05,{ }^{* *} p \leq 0.01$, and ${ }^{* * *} p \leq 0.001$.

\section{Results}

hTERT-MSC protect MIN6-cells from STZ-mediated injury Mesenchymal stem cells (MSC) are proposed to provide protection from organ damage by the release of growth factors and anti-inflammatory molecules. The effect is regarded as being dependent on the cell's tissue source and the distance of the MSC to the site of injury. Therefore, the protective outcome of hTERT-MSC on STZinjured MIN6-cells was examined comparing, first, direct cellular connection (DC) and, second, cells separated by an $8-\mu \mathrm{m}$ membrane that maintained the effect of molecules released in the medium (IDC). hTERT-MSC rescued the viability of about one-third of adjacent (DC) MIN6-cells damaged by rising STZ concentrations [0.5 mM (MIN6 $63 \pm 13.3 \%$ vs MIN6 + hTERT-MSC $87.4 \pm$ 10.2\%), 1.0 mM (MIN6 $45.8 \pm 10.4 \%$ vs MIN6 + hTERT- 

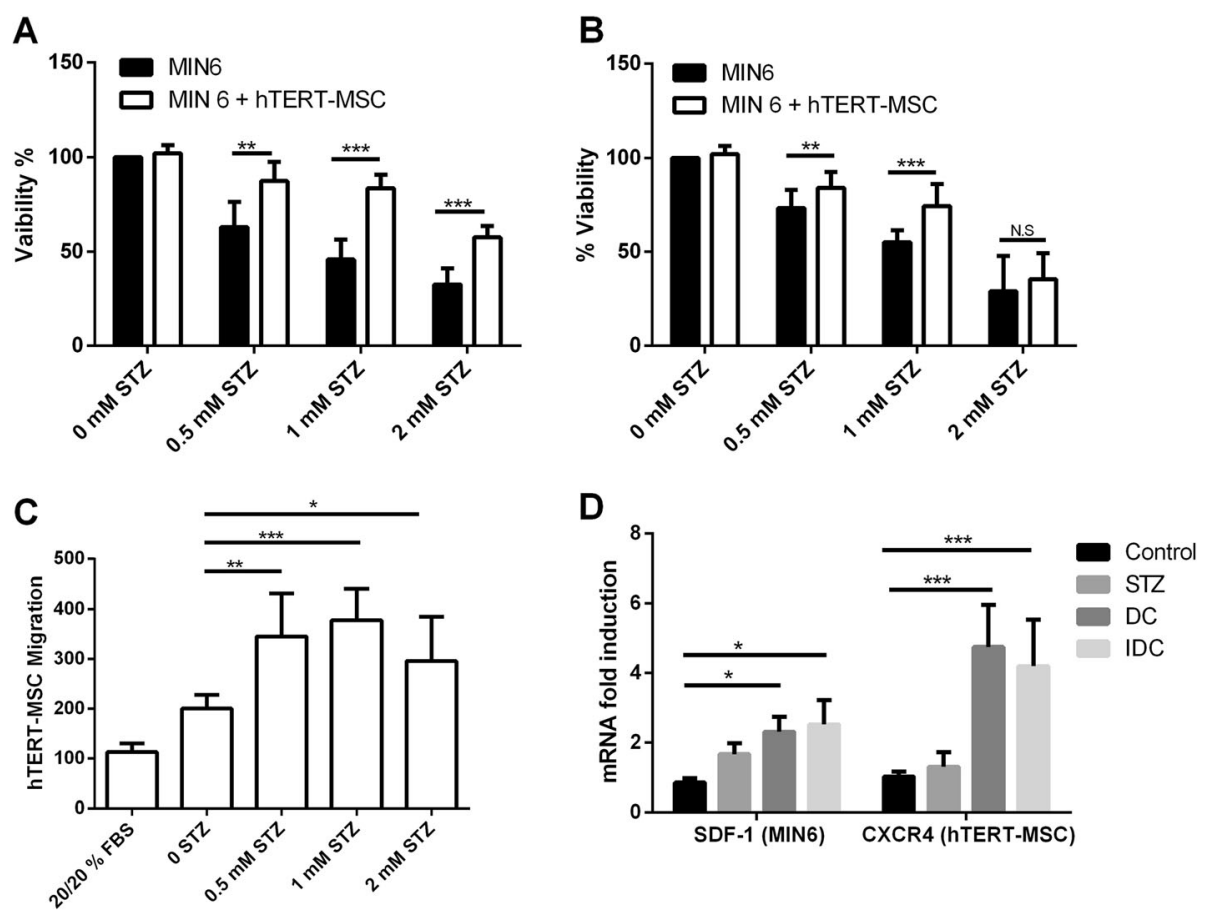

Fig. 1 hTERT-MSC migrate to damaged MIN6-cells and protect them from STZ toxicity. After treatment of MIN6-cells with 0.5, 1.0, or 2.0 mM STZ for $24 \mathrm{~h}$, hTERT-MSC were added to attain direct contact (DC) for $24 \mathrm{~h}$. For studying indirect paracrine effects (IDC), MIN6-cells were subjected to a transwell 96-well plate overnight and incubated for $24 \mathrm{~h}$ with STZ. On the next day, hTERT-MSC were added for $24 \mathrm{~h}$ to inserts of the wells separating them from MIN6-cells by a membrane with a pore size of $0.4 \mu \mathrm{m}$ to allow for diffusion of soluble factors only. The influence of hTERTMSC on the viability of MIN6-cells in DC (a) and IDC (b) at three concentrations of STZ (0.5, 1.0, and $2.0 \mathrm{mM})$ with MTT assay is demonstrated. The MIN6-cells' viability expressed is depicted in the percentage of untreated controls in the presence (STZ) and absence (control) of STZ with their respective controls. Approximately $60 \%$ viability was noticed in DC which reduced to $35 \%$ in IDC at $2.0 \mathrm{mM}$. c hTERT-MSC migration was evaluated on the membrane of the Boyden chamber with FDA staining in IDC. Unspecific background migration of hTERT-MSC was neutralized by considering 20\% FBS in both the chamber (Boyden chamber and well). d RT-PCR was employed to identify the expression of murine SDF-1 in MIN6-cells and human CXCR4 in hTERT-MSC. IDC, indirect culture; DC, direct culture; hTERT-MSC, human telomerase reverse transcriptase mesenchymal stem cells; CXCR-4, C-X-C chemokine receptor type 4; SDF1, stromal cell-derived factor 1. Data represent the mean \pm SEM, $n=4$. Value considered significant at $p \leq 0.05,{ }^{* *} p \leq 0.01$, and ${ }^{* * *} p \leq 0.001$

MSC $83.6 \pm 7.2 \%$ ), $2.0 \mathrm{mM}$ (MIN6 $32.6 \pm 8.5 \%$ vs MIN6 + hTERT-MSC $57.6 \pm 6 \%$ )] as shown in Fig. 1a. hTERTMSC also improved the viability of co-cultured MIN6cells under IDC conditions at $0.5 \mathrm{mM}$ (MIN6 $73.4 \pm$ 9.6\% vs MIN6 + hTERT-MSC $84.2 \pm 8.4 \%)$ and $1.0 \mathrm{mM}$ (MIN6 $55.4 \pm 6.4 \%$ vs MIN6 + hTERT-MSC $74.4 \pm$ $11.7 \%)$, but were incompetent to provide protection at $2.0 \mathrm{mM}$ (MIN6 29.1 $\pm 18.8 \%$ vs MIN6 + hTERT-MSC $35.4 \pm 13.9 \%$ ) concentration of STZ (Fig. 1b).

Next, cell migration towards STZ-injured MIN6-cells was examined. The directed movement of hTERT-MSC was triggered by all three STZ dosages $(0.5 \mathrm{mM}: p \leq$ $0.01,1.0 \mathrm{mM}, p \leq 0.001$; and at $2.0 \mathrm{mM}$ STZ: $p \leq 0.039$; Fig. 1c). Interestingly, chemotactic factor SDF-1 gene expression was induced in MIN6-cells in both co-culture systems (IDC: $p \leq 0.026$ and DC: $p \leq 0.041$ ). CXCR4 gene encoding the receptor specific for SDF-1 was expressed at both IDC $(p \leq 0.001)$ and DC $(p \leq 0.001)$ in hTERT-MSC (Fig. 1d).
Further, hTERT-MSC in direct or indirect co-culture with damaged MIN6-cells enhanced the synthesis of VEGF transcripts compared to MSC cultivated in the absence of MIN6-cells (Fig. 2a, DC (3.2 \pm 1.2$), p \leq 0.01$ and IDC (1.8 \pm 0.6$), p \leq 0.035)$. Similarly, transcripts of immunomodulatory factors TIMP-1 and IDO1 were statistically upregulated only in DC [TIMP-1 $(2.3 \pm 0.2)$, $p \leq 0.049$; IDO1 $(2.08 \pm 0.8), p \leq 0.04]$ but failed in IDC [TIMP-1 (1.5 \pm 0.3$), p \leq 0.068$; IDO1 $(1.49 \pm 0.8), p \leq$ 0.37] (Fig. 2a). The presence of hTERT-MSC preserved Ins2 expression in STZ-injured MIN6-cells (DC, $p \leq$ 0.006; IDC, $p \leq 0.0062$ ) in contrast to STZ-injured MIN6-cells only as shown in Fig. 2b.

The impact of hTERT-MSC on pathways crucial for insulin was further explored in MIN6-cells with Western blot. At 1.0-mM STZ treatment, phosphorylation of AKT protein ( $\mathrm{p}-\mathrm{AKT}$ ) was noticed in MIN6-cells in DC $(p \leq 0.0023)$ and IDC $(p \leq 0.0064)$ compared to STZ (Fig. 2c). Interestingly, higher phosphorylation of ERK protein 
A

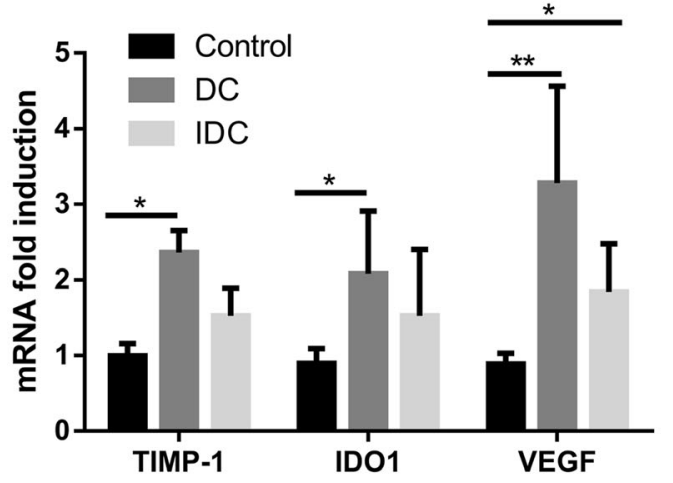

C
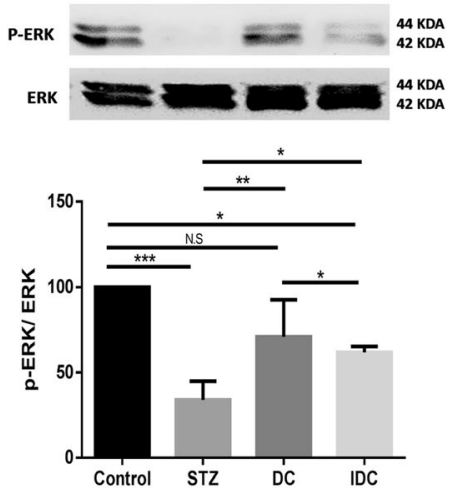
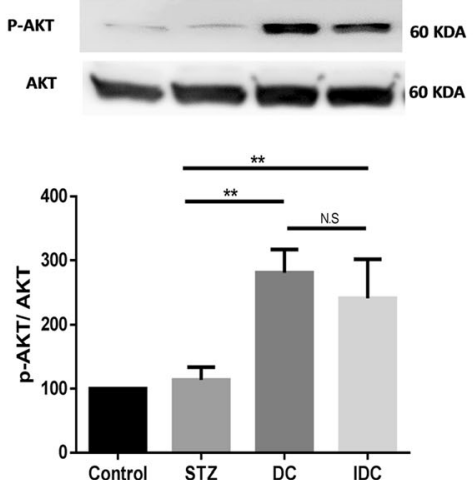

B

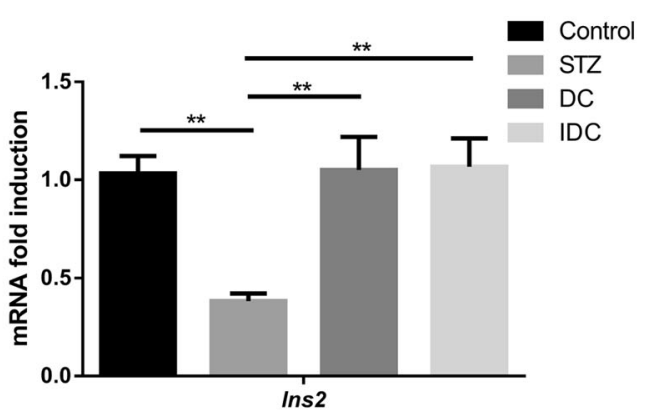

D

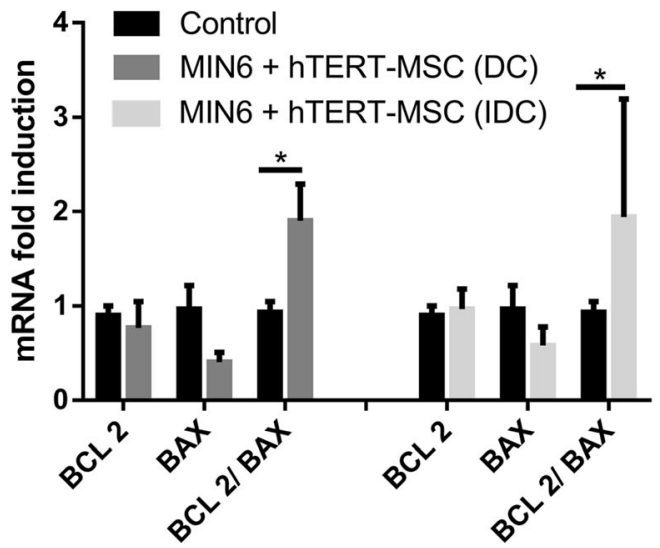

Fig. 2 Protective pathways activated in MIN6-cells by hTERT-MSC. a hTERT-MSC manufactured VEGF, IDO1, and TIMP-1 after interacting with STZinjured MIN6-cells in DC and IDC. Comparatively, higher expression of these molecules were observed in DC. Control is considered as healthy hTERT-MSC without physical or indirect contact with MIN6-cells. b The presence of hTERT-MSC in both conditions DC and IDC restored Ins2 gene expression in STZ-injured MIN6-cells. Control is considered as healthy MIN6-cells without STZ and hTERT-MSC influence. c The phosphorylation of AKT and ERK in damaged MIN6-cells with representative nitrocellulose membrane in upper and quantification of expressions in the lower panel with control adjusted to a hundred percent. A similar amount of phosphorylated AKT was detected in DC (280.8 \pm 36.40$)$ and IDC (241.4 \pm 50.29 ; $p \leq 0.341)$, but the higher $p$-ERK expression was noticed in DC (75.93 \pm 8.2$)$ compared to IDC $(59.18 \pm 2.4 ; p \leq 0.05)$. $\mathbf{d}$ Next, we hypothesized that p-AKT and p-ERK stimulated by hTERT-MSC influenced BCL-2 and BAX signaling cascade. In fact, MIN6-cells showed an increased BCL2/BAX ratio in the presence of MSC indicating a cellular state of anti-apoptosis. The four experimental conditions were identical to those described in Fig. 1. IDC, indirect culture; DC, direct culture; hTERT-MSC, human telomerase reverse transcriptase mesenchymal stem cells; IDO1, indoleamine 2,3dioxygenase 1; TIMP-1, TIMP metallopeptidase inhibitor 1; VEGF, vascular endothelial growth factor; Ins2, preproinsulin 2; ERK, extracellular signalregulated kinases; $A K T$, protein kinase $B ; B C L-2, B$ cell lymphoma 2; BAX, BCL-2-associated X protein. Data represent the mean $\pm S E M, n=4$. Value considered significant at $p \leq 0.05,{ }^{* *} p \leq 0.01$, and ${ }^{* * *} p \leq 0.001$

(p-ERK) was observed in DC than IDC $(p \leq 0.035)$ and STZ ( $p \leq 0.01$; Fig. 2 c). Further, the ratio of BCL-2 versus BAX was measured in both IDC $(p \leq 0.0428)$ and DC $(p \leq 0.0389)$ as illustrated in Fig. 2 d.

\section{Superior glycemic effect of intrapancreatic versus intravenous transfer of ADMSC}

To study the distinctive effects of local and systemic MSC transplantation in vivo, four experimental groups were followed, out of which IVR and IPR were transplanted with ADMSC (Fig. 3a). The overall non-fasting blood glucose concentration in NMRI nu/nu mice during the 30 -day follow-up was $8.7 \pm 1.8 \mathrm{mmol} / \mathrm{L}$. The injection of STZ resulted in blood glucose levels up to $19.5 \pm 5.3 \mathrm{mmol} / \mathrm{L}$ in mice without MSC treatment on day 10. ADMSC transplanted on day 7 decreased the mean blood glucose after 3 days in the IPR group $(11.5 \pm 4.1 \mathrm{mmol} / \mathrm{L}$; day 10$)$ compared to STZ only $(19.5 \pm 4.3 \mathrm{mmol} / \mathrm{L}, p \leq 0.0162 ;$ day 10$)$ and IVR (18.4 \pm $5.4 \mathrm{mmol} / \mathrm{L}, p \leq 0.003$; day 10$)$ as indicated in Fig. 3b. Throughout the follow-up till 30 days, the IPR group maintained lower mean blood glucose values $(12 \pm 4.4$ $\mathrm{mmol} / \mathrm{L}$; day 30$)$ as contrasted to STZ alone $(21.4 \pm 8.2$ $\mathrm{mmol} / \mathrm{L}, p \leq 0.0238$; day 30$)$, IVR $(18.8 \pm 8.1 \mathrm{mmol} / \mathrm{L}$; 

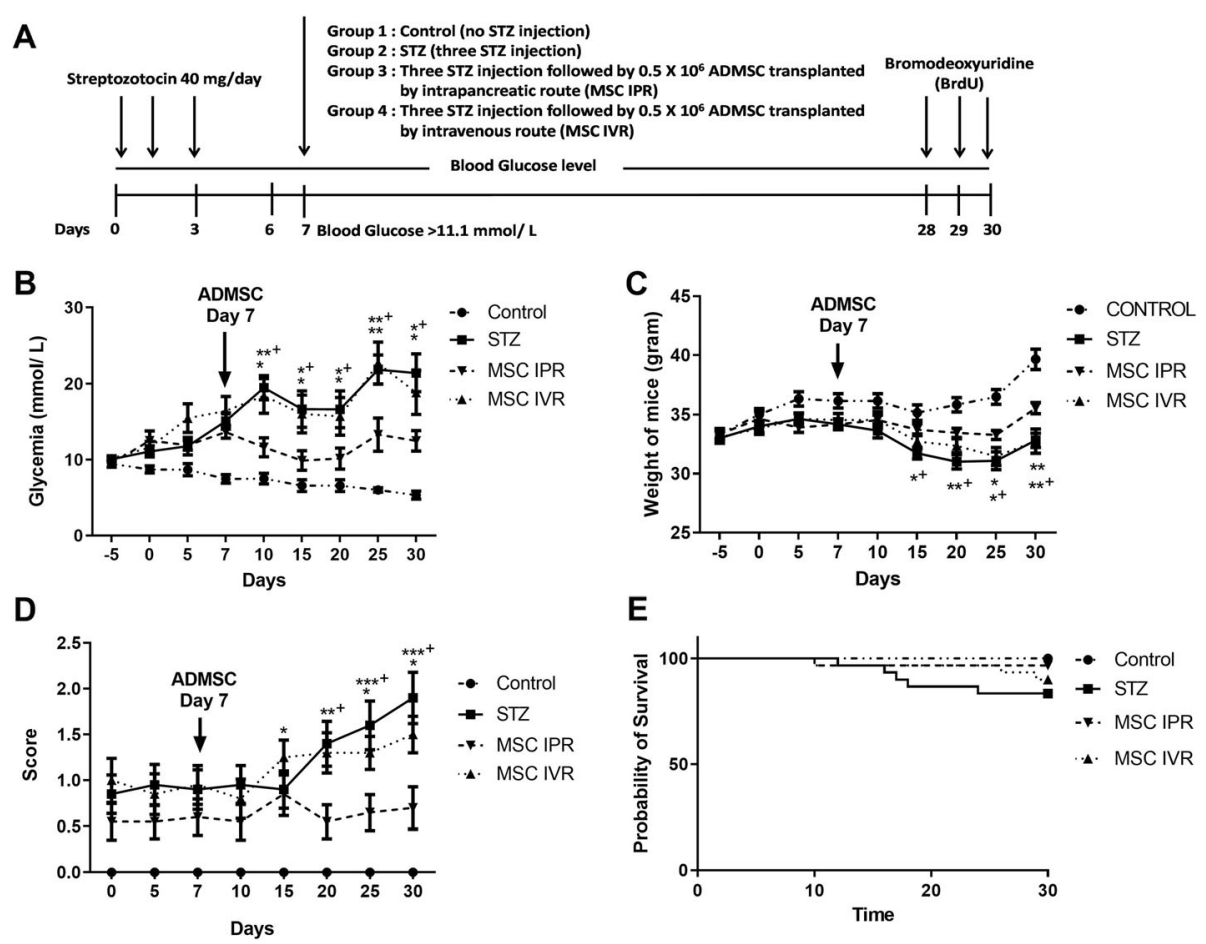

Fig. 3 Effect of ADMSC administration in diabetic NMRI nude mice. a Systematic representation of the experimental design. Three doses of STZ were injected to render the mice diabetic. After attaining blood glucose level above $11.1 \mathrm{mmol} / \mathrm{L}$ on day 7, ADMSC were administered with IPR and IVR. a Four experimental groups ( $n=11$ mice each) are represented in $\mathbf{a}$; control is non-diabetic and non-transplanted mice; STZ is STZinduced diabetic mice without ADMSC treatment; MSC-IVR is STZ-induced diabetic mice transplanted with ADMSC by intravenous route; MSC-IPR is STZ-induced diabetic mice transplanted with ADMSC by the intrapancreatic route. $\mathbf{b}$ The improved blood glucose profile after local transplantation of ADMSC (IPR) compared to the systemic route and STZ only group. $\mathbf{c}$ Body weight was measured throughout the experiment. At day 15, substantial variations were observed in the mean body weight of various groups. $\mathbf{d}$ The health score calculated from a list of health indicators designed for T1D (Table 2) in distinct groups. The IPR group exhibited a lower score as contrasted to others. e Survival rate remained insignificant for up to 30 days with a tendency of best survival in IPR as opposed to the IVR group. ADMSC, adipose tissue-derived mesenchymal stem cells; STZ, streptozotocin; IPR, intrapancreatic route; IVR, intravenous route; no STZ and no MSC, control. Data represent the mean \pm SEM, $n=11$. Value considered significant at $p<0.05,{ }^{* *} p \leq 0.01$, and ${ }^{* * *} p \leq 0.001 .{ }^{*+}$ Comparison between IPR and STZ and ${ }^{*}$ comparison between IPR and IVR

$p \leq 0.0373$; day 30$)$, and the non-diabetic control $(6.6 \pm$ $1.3 \mathrm{mmol} / \mathrm{L}, p \leq 0.0426$; day 30) (Fig. 3b).

Analogously, body weight varied from $33.7 \pm 1.2 \mathrm{~g}$ (day minus five) to day 15 in the IVR ( $32 \pm 2.1 \mathrm{~g})$, IPR (33.7 \pm $1.6 \mathrm{~g}), \mathrm{STZ}(31 \pm 1.6 \mathrm{~g})$, and non-diabetic control $(35 \pm 1.7$ g). On day 30 , a statistical significance was detected in IPR $(35 \pm 1.57 \mathrm{~g})$ compared to IVR $(32.75 \pm 2.91 \mathrm{~g}, p \leq 0.005)$, STZ $(32.8 \pm 1.99 \mathrm{~g}, p \leq 0.0024)$, and control $(39 \pm 2.06 \mathrm{~g}$, $p \leq 0.001)$ as presented in Fig. 3c. Health scores summarized from items listed in Table 2 exhibited a significant variation in the IPR versus STZ $(p \leq 0.001)$ and IVR $(p \leq$ 0.014 ) groups (Fig. 3d). The highest survival was displayed by the non-diabetic control (100\%) accompanied by IPR (96.6\%), IVR (90\%), and STZ (83.3\%) at the end of the experiment without achieving significance (Fig. 3e).

\section{Secure injection of ADMSC to the diabetic pancreas}

STZ was administered for three consecutive days followed by the transplantation of MSC via the above-mentioned routes. At day 30, vital organs such as the pancreas, spleen, heart, kidney, and lung were retrieved and weighed. Considerable variation was noticed in the pancreas weight $(204 \pm$ $3.92 \mathrm{mg}$ ) in IPR as opposed to STZ only (163 $\pm 5.18 \mathrm{mg}, p \leq$ $0.0012)$ and IVR $(183 \pm 4.76 \mathrm{mg}, p \leq 0.047)$ but not to the non-diabetic control group ( $215 \pm 7.37 \mathrm{mg}, p \leq 0.50$ ) (Fig. 4e) indicating that the injection procedure of ADMSC into the diabetic pancreas was reasonably atraumatic. The other organ weights remained unchanged during the observation time (Fig. 4a-d). After transplantation, ADMSC were tracked with the human Alu sequence. In IVR, human DNA was noticed in the lung $(1 / 10)$, kidney $(1 / 10)$, and pancreas $(1 / 10)$ whereas, in the IPR group, human DNA was encountered only in the pancreas $(2 / 10)$ at the end of the experiment (Supplement Figure S1).

\section{Pancreatic islet cell proliferation}

Cell replication rates were studied by injecting BrdU on three sequential days at the end of the experiment. The 
Table 2 Score sheet

\begin{tabular}{|c|c|}
\hline \multirow[t]{2}{*}{ Mouse identification: } & Date: \\
\hline & Time: \\
\hline 1. Body weight & Score \\
\hline \multicolumn{2}{|l|}{ Based on starting weight [} \\
\hline \multicolumn{2}{|l|}{ Based on the weight of the control group [} \\
\hline Uninfluenced or rise & 0 \\
\hline Reduction, but $<10 \%$ & 1 \\
\hline Reduction $>10 \%$ & 2 \\
\hline Reduction $>20 \%$ & 3 \\
\hline \multicolumn{2}{|l|}{ 2. General condition } \\
\hline $\begin{array}{l}\text { Shiny eyes, body openings and skin } \\
\text { clean }\end{array}$ & 0 \\
\hline $\begin{array}{l}\text { Cloudy eyes, increased muscle tone, } \\
\text { more visible breathing }\end{array}$ & 1 \\
\hline $\begin{array}{l}\text { Eyes sunken dull, sticky body openings, } \\
\text { increased breathing }\end{array}$ & 2 \\
\hline $\begin{array}{l}\text { Abnormal posture, animal feels cold, } \\
\text { eyes closed, cramps, paralysis, breathing } \\
\text { sounds, bluish mucous membranes, } \\
\text { diarrhoea }\end{array}$ & 3 \\
\hline \multicolumn{2}{|l|}{ 3. Spontaneous behaviour } \\
\hline $\begin{array}{l}\text { Attentive, curious, straightening, quick } \\
\text { movements }\end{array}$ & 0 \\
\hline $\begin{array}{l}\text { Decreased reactions, movement } \\
\text { reduced, restricted or excessive activity }\end{array}$ & 1 \\
\hline $\begin{array}{l}\text { Partial separation from the group, } \\
\text { movement reduced, pain when walking }\end{array}$ & 2 \\
\hline $\begin{array}{l}\text { Apathetic, no reaction or aggressiveness } \\
\text { in handling, severely restricted } \\
\text { movement, isolation, drag forward. }\end{array}$ & 3 \\
\hline \multicolumn{2}{|l|}{ 4. Trial-specific criteria } \\
\hline Blood sugar $<200$ mg/dl & 0 \\
\hline Blood sugar increased (> 200 mg/dl) & 1 \\
\hline Blood sugar increased (> 400 mg/dl) & 2 \\
\hline $\begin{array}{l}\text { Blood sugar reduced }(<60 \mathrm{mg} / \mathrm{dl}) \\
\text { At the same time, weight loss }\end{array}$ & 3 \\
\hline \multicolumn{2}{|l|}{ 5. Other termination criteria } \\
\hline Self-injury (e.g. excessive itching) & 3 \\
\hline Total score & \\
\hline
\end{tabular}

pancreases were retrieved and scrutinized by immunohistochemistry. Proliferating cells were identified as brown spots labeled with BrdU within the islets. They were co-stained with an anti-insulin antibody processed in blue color as displayed in Fig. 5a. An increased frequency of brown spots indicating replicating islet cells, both insulin positive and non-insulin positive per section, was detected in the IPR $(2.25 \pm 1.65)$ compared with STZ $(0.12 \pm 0.40, p \leq 0.001)$, IVR $(1.37 \pm 1.35, p \leq$ $0.005)$, and control $(0.35 \pm 0.73, p \leq 0.001)$ groups as described in Fig. 5b. Interestingly, not all BrdU-positive cells stained positive for insulin. However, none of the BrdU-positive cells stained positive for glucagon or somatostatin (Supplement Figures S2, S3, S4).

A similar observation was obtained when areas of islet sections [IPR $\left(2247.6 \pm 143.2 \mu \mathrm{m}^{2}\right)$ versus STZ (1546.8 \pm $\left.65.7 \mu \mathrm{m}^{2}\right)$, IVR $\left(1722.6 \pm 65.6 \mu \mathrm{m}^{2}\right)$, and non-diabetic control $\left.\left(4250.4 \pm 260.4 \mu \mathrm{m}^{2}\right)\right]$ and the number of islets per section [IPR $(4.8 \pm 2.8)$ were compared with STZ $(1.25 \pm 0.96, p \leq 0.001)$ and $\operatorname{IVR}(2.6 \pm 1.05, p \leq 0.002)]$ (Fig. 5c, d). In addition, mean insulin content in the blood and pancreas showed a non-significant increase in the sequence STZ, IVR, and IPR (Fig. 5e, f). A statistical discrepancy of total pancreatic insulin content was detected when comparing STZ $(9.2 \pm 7.6 \mathrm{ng}$ insulin $/ \mathrm{mg}$ of protein) and IPR $(32.17 \pm 7.6 \mathrm{ng}$ insulin/mg of protein; $p \leq 0.019)$.

\section{ADMSC operate through immune modulation, growth factors, and the ERK-DLK1 pathway}

Transcripts of growth factors VEGF, IGF-1, HGF, bFGF, and EGF in residual pancreatic tissue were quantitated with RT-PCR. The EGF expression was enhanced with ADMSC transplanted locally compared to systemic administration (IVR; $p \leq 0.0019)$, STZ $(p \leq 0.023)$, and non-diabetic control ( $p \leq 0.042$, Fig. 6a). No noteworthy variation was noticed in the expression of VEGF, IGF-1, HGF, and b-FGF (data not presented). Next, pro- and anti-inflammatory genes were investigated. Interestingly, the anti-inflammatory IL-10 expression was at a maximum in IPR compared to the other groups ( $p \leq 0.019$ versus control, Fig. 6a). Concomitantly, the expression of pro-inflammatory IL- $1 \beta$ and TNF- $\alpha$ was minimal in the IPR group (IL- $1 \beta, p \leq 0.020$ and TNF- $\alpha, p \leq 0.036$ compared with control), indicating the restoration of the Th1/Th2 equilibrium.

BAX promotes cell death through the permeabilization of the mitochondrial outer membrane in response to cellular stresses. In contrast, BCL-2 prevents apoptosis by inhibiting the activity of BAX. The ratio of antiapoptotic BCL-2 and apoptotic BAX gene expression was elevated in MSC-IPR compared to the untreated diabetic STZ group indicating a turn from a pro- to an anti-apoptotic environment by application of MSC ( $p \leq$ 0.05, Fig. 6b).

To explore the molecular mechanism mediating the proliferative and protective action of ADMSC, the pancreatic DLK1-ERK-FoxO1 signaling cascade was probed with RT-PCR. ADMSC administered into the pancreas increased the ERK $(p \leq 0.041)$ and decreased FoxO1 $(p \leq 0.034)$ expression as compared to the control group (Fig. 6c). Further, pancreatic DLK1 transcripts were enhanced comparing local (IPR) with systemic administration of ADMSC (IVR; $p \leq 0.001)$, STZ $(p \leq 0.001)$, and the non-diabetic control $(p \leq 0.001)$. 

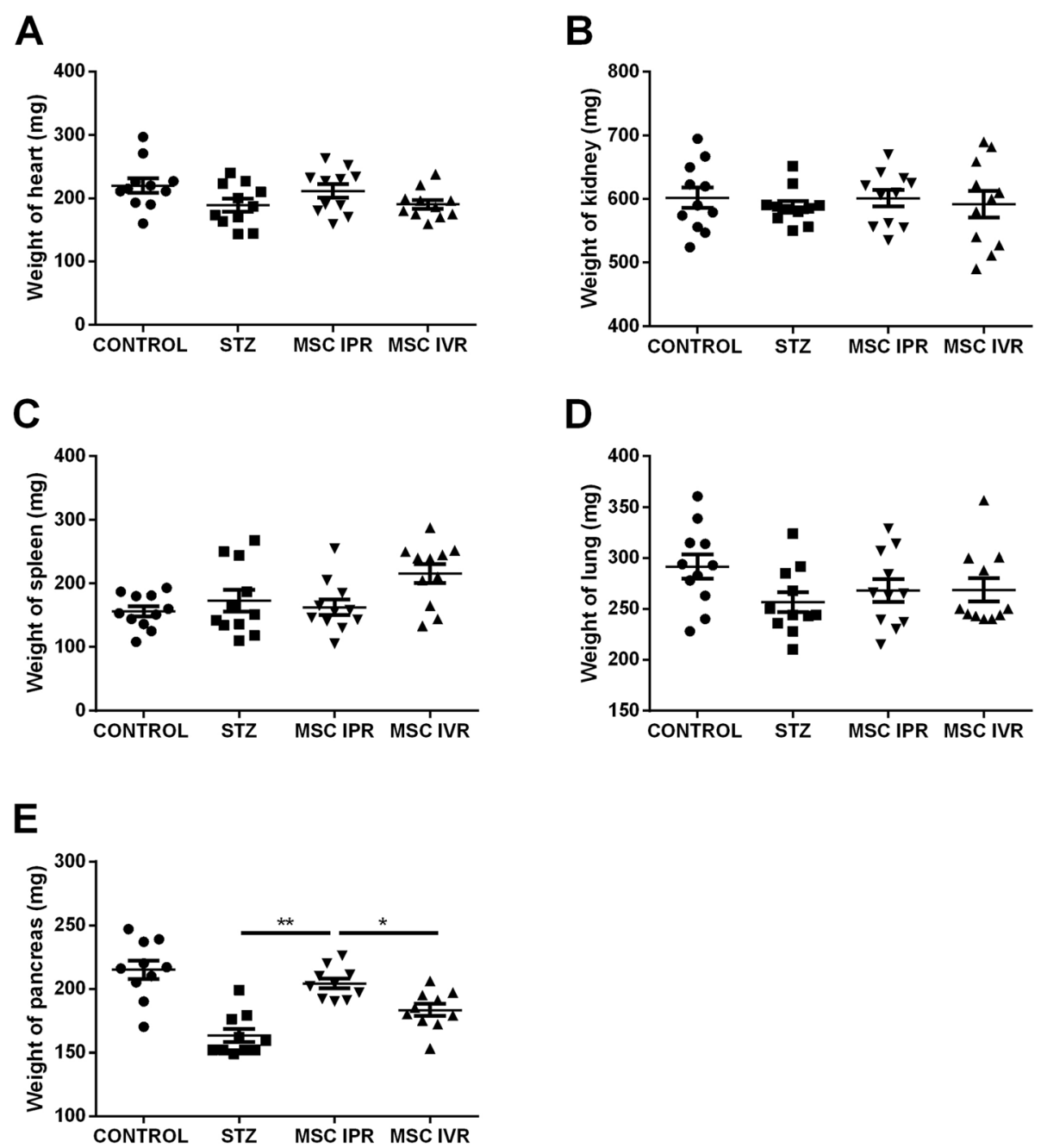

Fig. 4 ADMSC were administered in STZ-induced diabetic mice through IVR and IPR. At day 30, organs were retrieved and weighed. a-d The weights of the heart, kidney, spleen, and lung. No variations were assessed among groups. e A considerable reduction of mean pancreatic weight was noted in STZ and IVR groups compared to IPR. Interestingly, no significant difference was detected between control and IPR body weights. STZ, streptozotocin; IPR, intrapancreatic route; IVR, intravenous route; no STZ and no MSC, control. Data represent the mean \pm SEM, $n=$ 11. Value considered significant at $p \leq 0.05,{ }^{* *} p \leq 0.01$, and ${ }^{* * *} p \leq 0.001$

\section{Discussion}

The substitution of $\beta$ cells for T1D patients is a major therapeutic challenge. Recently, embryonic, induced pluripotent, and mesenchymal stem cells have been employed to replace $\beta$ cells [28-34]. Administration of MSC is advantageous over other stem cells as they ward off the risk of teratoma formation for the recipient [3537]. In our study, ADMSC were transplanted subcutaneously into NMRI nude mice and observed for 42 days to exclude tumor formation (data not shown). As per International Society Cell and Gene Therapy, MSC are required to be characterized for their cell surface markers (CD44+, CD105+, CD73+, and CD90+), fibroblastic-like structure, and surface adherence properties [25].

MSC are reported to entangle into the lung's microvasculature after the systemic administration. However,
MSC transplanted along with islets improved sustainability and overall engraftment in patients, but it is still ambiguous whether physical contact between MSC and pancreatic $\beta$ cell is demanded, or a paracrine effect of soluble factors is sufficient [38]. Therefore, we compared the two diverse routes, i.e., local transplantation with cells injected directly into pancreatic parenchyma, and systemic transplantation with ADMSC administered through the tail vein in STZ-induced diabetic NMRI nude mice. This in vivo model was translated to in vitro culture condition to explore intercellular communication on the molecular level. DC and IDC contact of hTERTMSC (human) with STZ-damaged MIN6-cells (mouse) was investigated.

Higher viability of STZ-injured MIN6-cells after coculture with MSC in physical contact (DC) was found. 


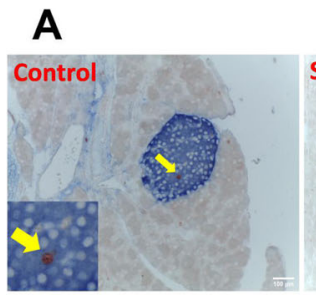

B

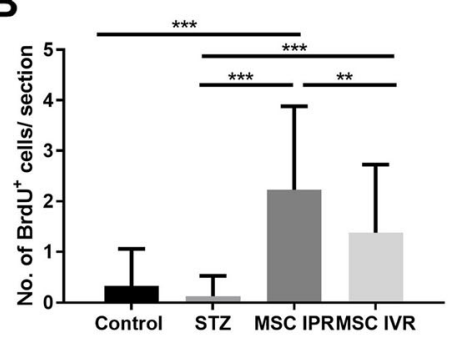

D
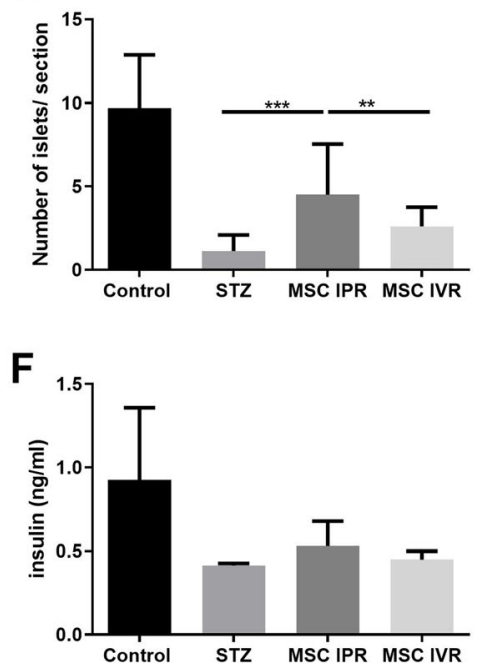

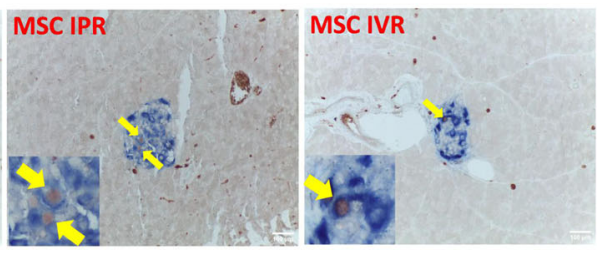

C

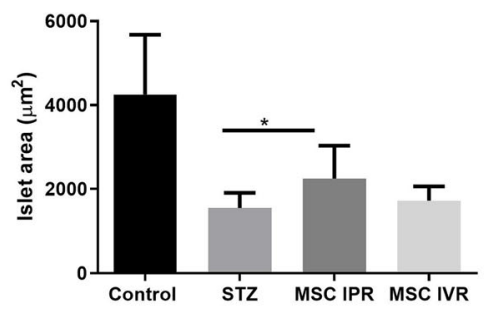

E

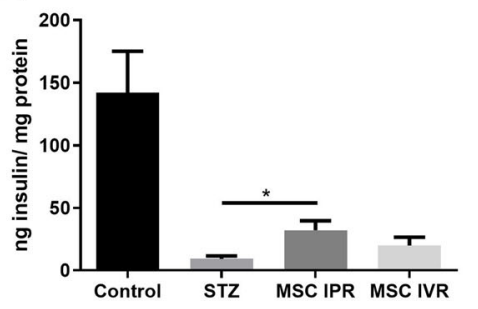

Fig. 5 The morphometry of pancreatic islets after ADMSC administration in STZ-induced diabetic mice. a Pancreatic histological analysis of proliferating islet cells tagged with BrdU (brown color) within the islets (insulin stain in blue color) was achieved with immunohistochemistry. b The number of BrdU-positive cells per section replicating within the islets. $\mathbf{c}$ Islet area was significantly increased in the IPR group compared to others and $\mathbf{d}$ islet per section also adopted an identical trend. $\mathbf{e}, \mathbf{f}$ The insulin content measured with ELISA in the pancreas and blood of their respective groups. STZ, streptozotocin; IPR, intrapancreatic route; BrdU, bromodeoxyuridine; IVR, intravenous route; no STZ and no MSC, control. Data represent the mean $\pm \mathrm{SEM}, n=6,{ }^{*} p \leq 0.05$

By contrast, IDC failed to sustain an analogous effect to MIN6-cells exposed to $2.0 \mathrm{mM}$ STZ. MSC administered through the IVR route showed a restricted migration towards STZ-damaged pancreatic tissue. Therefore, employing the Boyden chamber, MSC migration was assessed towards STZ-damaged MIN6-cells. The expression of SDF-1 (CXCL12) was increased in STZ-damaged MIN6-cells, suggesting that CXCR4 expressing MSC in both DC and IDC were attracted. After interacting with injured MIN6-cells, the MSC manufactured a higher amount of TIMP-1, IDO1, and VEGF in DC which maintained insulin transcript integrity of Ins2 in MIN6cells. These results were in conformity with the literature, for instance, increased SDF-1 expression was observed for 7 days in a mouse model of acute pancreatitis. Moreover, IDO1, VEGF, and TIMP-1 were conferred for tissue maintenance [39-41]. Further, both AKT - and ERK-mediated pathways were activated in DC and IDC, but phosphorylation of ERK was more enhanced in DC as compared to IDC. Both DC and IDC were observed to grant protection of the pancreatic $\beta$ cells through BCL-2/BAX.

Different routes of MSC transplantation for T1D therapy are still debatable in preclinical and clinical studies. The supreme route should provide foremost regeneration with the lowest side effect $[42,43]$. Yaochite et al. 

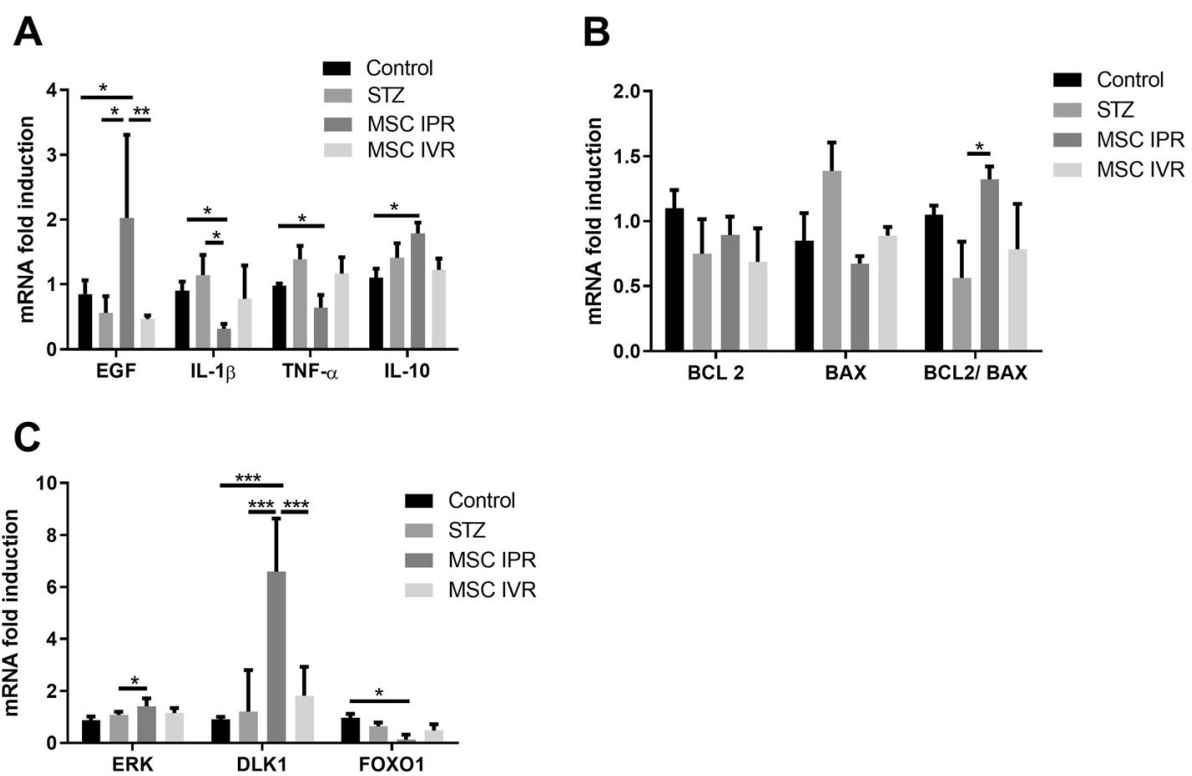

Fig. 6 Protective effect of ADMSC in STZ-induced diabetic mice through growth factors, immunomodulation, and the pancreatic DLK1-ERKFoxO1 signaling cascade. a Growth factor (EGF) and pro- and anti-inflammatory transcripts (IL-1 $\beta$, TNF- $a$, and IL-10) were measured at the end of the experiment. A higher EGF expression and anti-inflammatory equilibrium was facilitated by ADMSC. $\mathbf{b}$ Decreased apoptosis after ADMSC administration through the anti-apoptotic (BCL-2) and BAX (apoptotic) molecule ratio was noticed in the IPR group. c Pancreatic gene expression of ERK, FoxO1, and DLK1 was determined with RT-PCR after 30 days to STZ injection in all the groups. STZ, streptozotocin; EGF, epidermal growth factor; FoxO1, forkhead box 1; TNF-a, tumor necrosis factor-alpha; IL-1 $\beta$, interleukin 1 beta; IL-10, interleukin-10; BCL-2, B cell lymphoma 2; BAX, BCL-2-associated X protein; DLK1, delta-like non-canonical notch ligand 1; ERK, extracellular signal-regulated kinases; IPR, intrapancreatic route; IVR, intravenous route; no STZ and no MSC, control. Data show the mean \pm SEM, $n=3$ or 4 . Value considered significant at $p \leq 0.05$, ${ }^{* *} p<0.01$, and ${ }^{* *} p \leq 0.001$

claimed a stronger effect of the intrasplenic administration of MSC over the intrapancreatic route [19]. Similarly, the intravenous infusion of human umbilical cordderived MSC had a greater impact than the intrapancreatic one [15]. However, a recent study revealed the dominance of the intrapancreatic infusion in balancing blood glucose level by reducing Iba1-positive and CD40 cells over the intravenous route [20]. Our study further reinforces this recent outcome and claims the superior antidiabetic effect of intrapancreatic infusion of MSC.

In this study, IPR-ADMSC administration displayed lower mean blood glucose and higher body weight after $10-15$ days. No such impact was noted in IVR as discussed in the literature [44]. This could be because of the discrepancy in the murine strains or the initial number of MSC being too low $\left(0.5 \times 10^{6}\right)$. It could be further presumed that after transplantation, the majority of MSC were entrapped into the lungs and failed to reach the damaged pancreas for a salutary effect. In our study, after 30 days, ADMSC-DNA was noticed in the lung, kidney, and pancreas after systemic administration (Figure S1). Murai et al. also pointed out the non-functional outcome of intravenous injection in T1D, which supports our results. Further, both the mouse-health-score follow-up and the survival rate confirmed the higher curative effect of IPR infusion over IVR and STZ groups from diabetic symptoms. Likewise, increased pancreatic weight was recorded, which is amalgamated with accelerated recovery from diabetic stress within the short window of 30 days.

We next addressed the increase in pancreatic islet cell replication after IPR injection. Proliferating pancreatic $\beta$ cells were reported in the neonatal and fetal stages. This proliferative potential rapidly wanes in adult cells [45]. The IPR-ADMSC administration displayed an increased number in replicating islet cells along with an increased pancreatic islet area compared to control and IVR. Surprisingly, rare but low proliferation was further observed in the control group. Recently, it was reported that an immature $\beta$ cell niche remained throughout life and acted as a source of insulin-producing $\beta$ cells [46]. No such effect was observed in diabetic mice that had received STZ without ADMSC. Similarly, pancreatic insulin also featured an analogous pattern.

The MSC secretome was reported to counteract the pro-apoptotic microenvironment in the diabetic pancreas [47-50]. Our experiment conforms with these publications as the EGF and IL-10 genes were up- and pro-inflammatory IL- $1 \beta$ and TNF- $\alpha$ were downregulated in the MSC-IPR group. Similarly, anti-apoptotic signaling with the BCL-2 versus BAX ratio was most pronounced in the IPR as contrasted to the other groups. In 


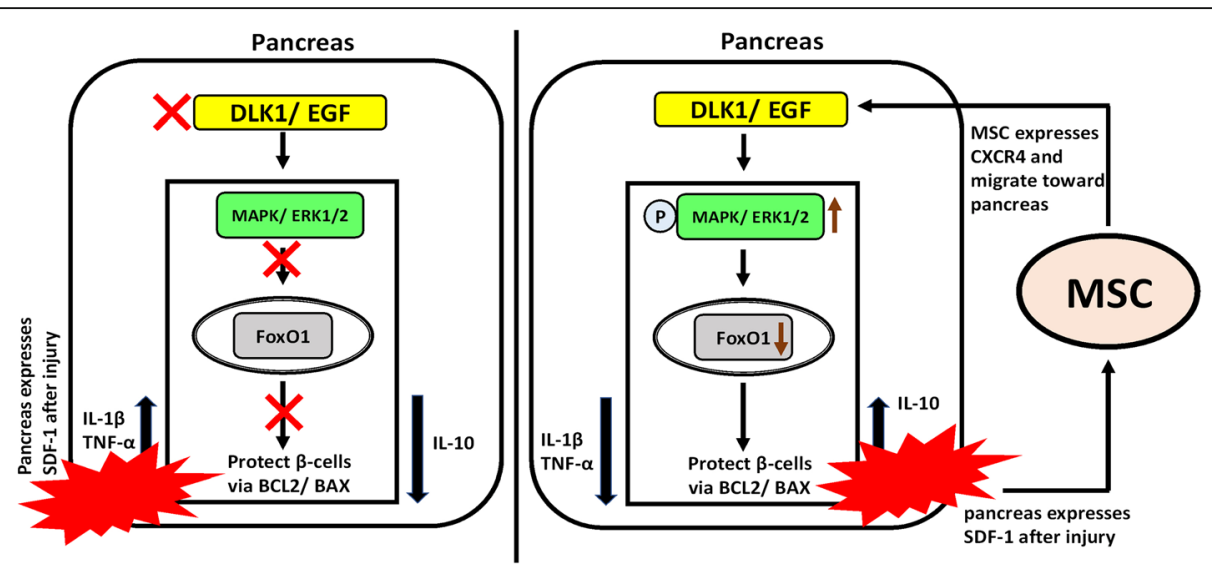

Fig. 7 Diagrammatic representation of MSC's proposed mechanism of protection in STZ-induced diabetic mice. a The diabetic pancreas without MSC. b IPR administration into the diabetic pancreas stimulates the DLK1-ERK-FoxO1 signaling cascade

vitro studies proposed a role of AKT- and ERKmediated pathway. Therefore, both were studied, and a predominantly higher expression of ERK was detected in the IPR. Further, the FoxO1 nuclear export has a significant impact on $\beta$ cell proliferation, and the ERK signaling cascade has the potential to modulate it [51, 52]. The FoxO1 expression was seen downregulated in the IPR group. Further, activated DLK1 was noticed after MSC injection through IPR in T1D NMRI nude mice. In the past, DLK1 was linked with the inhibition of adipogenic differentiation [53]. It further cooperates in MSC differentiation as its overexpression influenced the ERK and FoxO1 signaling cascade $[54,55]$. DLK1 expresses during embryonic development in the pancreas and declines rapidly after birth [56]. However, a DLK1 receptor is still unknown [57]. This study provides insight into its signaling cascade and points to the antidiabetic influence of MSC-IPR administration which will be feasible to be employed in T1D treatment.

\section{Conclusion}

Our study delivers further evidence for a superior antidiabetic effect of the local/intrapancreatic (IPR) administration of ADMSC as compared to the systemic/intravenous (IVR) administration in STZ-induced diabetic mice. The local transplantation improved both glycemic control and the animals' body weight significantly through endogenous pancreatic islet cell replication and EGF release. Further, the IPR route resulted in the regulation of the host's immune system and the induction of the pancreatic DLK1-ERK-FoxO1 signaling cascade (Fig. 7).

\section{Supplementary Information}

The online version contains supplementary material available at https://doi. org/10.1186/s13287-021-02173-4.

Additional file 1.

\section{Abbreviations}

IDC: Indirect culture; DC: Direct culture; hTERT-MSC: Human telomerase reverse transcriptase mesenchymal stem cells; DMEM: Dulbecco's modified Eagle's medium; CXCR-4: C-X-C chemokine receptor type 4; SDF1: Stromal cell-derived factor 1; IDO1: Indoleamine 2,3-dioxygenase 1; TIMP-1: TIMP metallopeptidase inhibitor 1; VEGF: Vascular endothelial growth factor; ANOVA: Analysis of variance; Ins2: Preproinsulin 2; ERK: Extracellular signalregulated kinases; AKT: Protein kinase B; BCL-2: B cell lymphoma 2; BAX: BCL2-associated $X$ protein; $m R N A$ : Messenger ribonucleic acid;

STZ: Streptozotocin; EGF: Epidermal growth factor; FoxO1: Forkhead box 1; FDA: Fluorescein diacetate; TNF-a: Tumor necrosis factor-alpha; IL-

1ß: Interleukin 1 beta; IL-10: Interleukin-10; DLK1: Delta-like non-canonical notch ligand 1; IPR: Intrapancreatic route; IVR: Intravenous route; c-

DNA: Complementary deoxyribonucleic acid; ESC: Embryonic stem cells; iPSC: Induced pluripotency stem cell; T1D: Type 1 diabetes; $\beta$ cells: Beta cells; BrdU: Bromodeoxyuridine; ADMSC: Adipose-derived mesenchymal stem cells; RT-PCR: Quantitative real-time polymerase chain reaction; PBS: Phosphatebuffered saline; FBS: Fetal bovine serum; SEM: Standard error of the mean; NMRI: The Naval Medical Research Institute; DMSO: Dimethyl sulfoxide; MTT: 3-(4,5-Dimethylthiazol-2-yl)-2,5-diphenyl tetrazolium bromide; MIN6cells: Mouse insulinoma 6 cells

\section{Acknowledgements}

We would like to thank Prof Heinrich Sauer (Physiological Institute, Department of Medicine, Justus Liebig University, Giessen) for isolating ADMSC from fat utilized in this study and Prof. Peter Czermak (Mittelhessen University of Applied Sciences, Giessen) for providing hTERT-MSC. Additionally, we acknowledge the effort of Birte Hussmann for arranging animal experiments and Gundula Hertl for calculating the number of BrdU-positive cells and islets as an external evaluator. We would also like to thank Deutscher Akademischer Auslandsdienst (DAAD) for financial support in Graduate School Scholarship Program.

\section{Authors' contributions}

RK conducted the experiments, analyzed the data, and wrote the manuscript. SFP edited and reviewed the manuscript. TL analyzed the data, conceived the experiments, and reviewed the manuscript. The authors read and approved the final manuscript.

\section{Funding}

This work was supported by a grant from Deutscher Akademischer Auslandsdienst program "Lipids in Nutrition, and Metabolism." The funders had no role in the study design, data collection, and analysis; decision to publish; or preparation of the manuscript. Open Access funding enabled and organized by Projekt DEAL.

Availability of data and materials

All relevant data and material to reproduce the findings are available in the manuscript. 


\section{Ethics approval and consent to participate}

The experimental procedures were approved by the ethical committee according to the German Animal Welfare Law and Guidelines under the code $31 / 2017$. The fat retrieval was approved by the Institutional review board of the Faculty of Medicine (Reg.- No 141/04) at Justus Liebig University, Giessen.

\section{Consent for publication}

Not applicable

\section{Competing interests}

The authors declare no competing interests.

\section{Received: 25 March 2020 Accepted: 19 January 2021} Published online: 12 February 2021

\section{References}

1. Katsarou A, Gudbjornsdottir S, Rawshani A, Dabelea D, Bonifacio E, Anderson BJ, Jacobsen LM, Schatz DA, Lernmark A. Type 1 diabetes mellitus. Nat Rev Dis Primers. 2017;3:17016.

2. Ogurtsova K, da Rocha Fernandes JD, Huang Y, Linnenkamp U, Guariguata L, Cho NH, Cavan D, Shaw JE, Makaroff LE. IDF Diabetes Atlas: global estimates for the prevalence of diabetes for 2015 and 2040. Diabetes Res Clin Pract. 2017;128:40-50.

3. Xia Y, Xie Z, Huang G, Zhou Z. Incidence and trend of type 1 diabetes and the underlying environmental determinants. Diabetes Metab Res Rev. 2019; 35(1):e3075.

4. DiMeglio LA, Evans-Molina C, Oram RA. Type 1 diabetes. Lancet. 2018; 391(10138):2449-62.

5. Pixley JS. Mesenchymal stem cells to treat type 1 diabetes. Biochim Biophys Acta Mol Basis Dis. 2020;1866(4):16531.

6. Ulyanova O, Askarov M, Kozina L, Karibekov T, Shaimardanova G, Zhakupova A, Danilova D, Serebrennikova D. Autologous mesenchymal stem cell transplant in patients with type 1 diabetes mellitus. Exp Clin Transplant. 2019;17(Suppl 1):236-8.

7. Path G, Perakakis N, Mantzoros CS, Seufert J. Stem cells in the treatment of diabetes mellitus - focus on mesenchymal stem cells. Metabolism. 2019;90: $1-15$.

8. Brown C, McKee C, Bakshi S, Walker K, Hakman E, Halassy S, Svinarich D, Dodds R, Govind CK, Chaudhry GR. Mesenchymal stem cells: Cell therapy and regeneration potential. J Tissue Eng Regen Med. 2019;13(9):1738-55.

9. Rekittke NE, Ang M, Rawat $D$, Khatri $R$, Linn T. Regenerative therapy of type 1 diabetes mellitus: from pancreatic islet transplantation to mesenchymal stem cells. Stem Cells Int. 2016;2016:3764681.

10. Moreira A, Kahlenberg S, Hornsby P. Therapeutic potential of mesenchymal stem cells for diabetes. J Mol Endocrinol. 2017:59(3):R109-20.

11. Pittenger MF, Mackay AM, Beck SC, Jaiswal RK, Douglas R, Mosca JD, Moorman MA, Simonetti DW, Craig S, Marshak DR. Multilineage potential of adult human mesenchymal stem cells. Science. 1999;284(5411):143-7.

12. Ma S, Xie N, Li W, Yuan B, Shi Y, Wang Y. Immunobiology of mesenchymal stem cells. Cell Death Differ. 2014;21(2):216-25.

13. Yin Y, Hao H, Cheng Y, Zang L, Liu J, Gao J, Xue J, Xie Z, Zhang Q, Han W, et al. Human umbilical cord-derived mesenchymal stem cells direct macrophage polarization to alleviate pancreatic islets dysfunction in type 2 diabetic mice. Cell Death Dis. 2018;9(7):760.

14. Carlsson PO, Schwarcz E, Korsgren O, Le Blanc K. Preserved beta-cell function in type 1 diabetes by mesenchymal stromal cells. Diabetes. 2015; 64(2):587-92.

15. Phan NK, Duong TT, Pham TL-B, Dang LT-T, Bui AN-T, Pham VM, Truong NC, Van Pham P. Preliminary evaluation of intravenous infusion and intrapancreatic injection of human umbilical cord blood-derived mesenchymal stem cells for the treatment of diabetic mice. Biomed Res Ther. 2014:1(3).

16. Wang M, Liang C, Hu H, Zhou L, Xu B, Wang X, Han Y, Nie Y, Jia S, Liang J, et al. Intraperitoneal injection (IP), intravenous injection (IV) or anal injection (Al)? Best way for mesenchymal stem cells transplantation for colitis. Sci Rep. 2016;6:30696.

17. Zhang X, Yamaoka K, Sonomoto K, Kaneko H, Satake M, Yamamoto $Y$, Kondo M, Zhao J, Miyagawa I, Yamagata K, et al. Local delivery of mesenchymal stem cells with poly-lactic-co-glycolic acid nano-fiber scaffold suppress arthritis in rats. PLoS One. 2014;9(12):e114621.
18. Lundberg J, Sodersten E, Sundstrom E, Le Blanc K, Andersson T, Hermanson $\mathrm{O}$, Holmin S. Targeted intra-arterial transplantation of stem cells to the injured CNS is more effective than intravenous administration: engraftment is dependent on cell type and adhesion molecule expression. Cell Transplant. 2012;21(1):333-43.

19. Yaochite JN, Caliari-Oliveira C, de Souza LE, Neto LS, Palma PV, Covas DT, Malmegrim KC, Voltarelli JC, Donadi EA. Therapeutic efficacy and biodistribution of allogeneic mesenchymal stem cells delivered by intrasplenic and intrapancreatic routes in streptozotocin-induced diabetic mice. Stem Cell Res Ther. 2015;6:31.

20. Murai N, Ohtaki H, Watanabe J, Xu Z, Sasaki S, Yagura K, Shioda S, Nagasaka S, Honda K, Izumizaki M. Intrapancreatic injection of human bone marrowderived mesenchymal stem/stromal cells alleviates hyperglycemia and modulates the macrophage state in streptozotocin-induced type 1 diabetic mice. PLoS One. 2017;12(10):e0186637.

21. de Souza BM, Boucas AP, Oliveira FD, Reis KP, Ziegelmann P, Bauer AC, Crispim D. Effect of co-culture of mesenchymal stem/stromal cells with pancreatic islets on viability and function outcomes: a systematic review and meta-analysis. Islets. 2017;9(2):30-42.

22. Liu C, Zhang W, Peradze N, Lang L, Straetener J, Feilen PJ, Alt M, Jager C, Laubner K, Perakakis N, et al. Mesenchymal stem cell (MSC)-mediated survival of insulin producing pancreatic beta-cells during cellular stress involves signalling via Akt and ERK1/2. Mol Cell Endocrinol. 2018;473:235-44.

23. Rackham CL, Dhadda PK, Le Lay AM, King AJ, Jones PM. Preculturing islets with adipose-derived mesenchymal stromal cells is an effective strategy for improving transplantation efficiency at the clinically preferred intraportal site. Cell Med. 2014;7(1):37-47.

24. Karaoz E, Ayhan S, Okcu A, Aksoy A, Bayazit G, Osman Gurol A, Duruksu G. Bone marrow-derived mesenchymal stem cells co-cultured with pancreatic islets display beta cell plasticity. J Tissue Eng Regen Med. 2011;5(6):491-500.

25. Doering L, Khatri R, Petry SF, Sauer H, Howaldt HP, Linn T. Regulation of somatostatin expression by vitamin D3 and valproic acid in human adiposederived mesenchymal stem cells. Stem Cell Res Ther. 2019;10(1):240.

26. Lai Y, Schneider D, Kidszun A, Hauck-Schmalenberger I, Breier G, Brandhorst $D$, Brandhorst H, Iken M, Brendel MD, Bretzel RG, et al. Vascular endothelial growth factor increases functional beta-cell mass by improvement of angiogenesis of isolated human and murine pancreatic islets. Transplantation. 2005;79(11):1530-6.

27. Samikannu B, Chen C, Lingwal N, Padmasekar M, Engel FB, Linn T. Dipeptidyl peptidase IV inhibition activates CREB and improves islet vascularization through VEGF-ANEGFR-2 signaling pathway. PLoS One. 2013;8(12):e82639.

28. Naujok O, Francini F, Picton S, Jorns A, Bailey CJ, Lenzen S. A new experimental protocol for preferential differentiation of mouse embryonic stem cells into insulin-producing cells. Cell Transplant. 2008;17(10-11):1231-42

29. Shahjalal HM, Abdal Dayem A, Lim KM, Jeon TI, Cho SG. Generation of pancreatic beta cells for treatment of diabetes: advances and challenges. Stem Cell Res Ther. 2018;9(1):355.

30. D'Amour KA, Agulnick AD, Eliazer S, Kelly OG, Kroon E, Baetge EE. Efficient differentiation of human embryonic stem cells to definitive endoderm. Nat Biotechnol. 2005;23(12):1534-41.

31. Rezania A, Bruin JE, Arora P, Rubin A, Batushansky I, Asadi A, O'Dwyer S, Quiskamp N, Mojibian M, Albrecht T, et al. Reversal of diabetes with insulinproducing cells derived in vitro from human pluripotent stem cells. Nat Biotechnol. 2014;32(11):1121-33.

32. Zhang D, Jiang W, Liu M, Sui X, Yin X, Chen S, Shi Y, Deng H. Highly efficient differentiation of human ES cells and iPS cells into mature pancreatic insulin-producing cells. Cell Res. 2009;19(4):429-38.

33. Timper K, Seboek D, Eberhardt M, Linscheid P, Christ-Crain M, Keller U, Muller B, Zulewski H. Human adipose tissue-derived mesenchymal stem cells differentiate into insulin, somatostatin, and glucagon expressing cells. Biochem Biophys Res Commun. 2006;341(4):1135-40.

34. Wu H, Mahato RI. Mesenchymal stem cell-based therapy for type 1 diabetes. Discov Med. 2014;17(93):139-43.

35. Galipeau J, Sensebe L. Mesenchymal stromal cells: clinical challenges and therapeutic opportunities. Cell Stem Cell. 2018;22(6):824-33.

36. Chulpanova DS, Kitaeva KV, Tazetdinova LG, James V, Rizvanov AA, Solovyeva W. Application of mesenchymal stem cells for therapeutic agent delivery in anti-tumor treatment. Front Pharmacol. 2018;9:259.

37. Schroder C, Khatri R, Petry SF, Linn T. Class I and II histone deacetylase inhibitor LBH589 promotes endocrine differentiation in bone marrow 
derived human mesenchymal stem cells and suppresses uncontrolled proliferation. Exp Clin Endocrinol Diabetes. 2020.

38. Wang H, Strange C, Nietert PJ, Wang J, Turnbull TL, Cloud C, Owczarski S, Shuford B, Duke T, Gilkeson G, et al. Autologous mesenchymal stem cell and islet cotransplantation: safety and efficacy. Stem Cells Transl Med. 2018; 7(1):11-9.

39. Lee RH, Pulin AA, Seo MJ, Kota DJ, Ylostalo J, Larson BL, Semprun-Prieto L, Delafontaine P, Prockop DJ. Intravenous hMSCs improve myocardial infarction in mice because cells embolized in lung are activated to secrete the anti-inflammatory protein TSG-6. Cell Stem Cell. 2009:5(1):54-63.

40. Steingen C, Brenig F, Baumgartner L, Schmidt J, Schmidt A, Bloch W. Characterization of key mechanisms in transmigration and invasion of mesenchymal stem cells. J Mol Cell Cardiol. 2008;44(6):1072-84.

41. Gong J, Meng HB, Hua J, Song ZS, He ZG, Zhou B, Qian MP. The SDF-1/ CXCR4 axis regulates migration of transplanted bone marrow mesenchymal stem cells towards the pancreas in rats with acute pancreatitis. Mol Med Rep. 2014;9(5):1575-82.

42. Kurtz A. Mesenchymal stem cell delivery routes and fate. Int I Stem Cells. 2008; (1):1-7.

43. Li L, Hui H, Jia X, Zhang J, Liu Y, Xu Q, Zhu D. Infusion with human bone marrow-derived mesenchymal stem cells improves beta-cell function in patients and non-obese mice with severe diabetes. Sci Rep. 2016;6:37894.

44. Dang LT, Bui AN, Le-Thanh Nguyen C, Truong NC, Bui AT, Kim NP, Truong KD, Van Pham P. Intravenous infusion of human adipose tissue-derived mesenchymal stem cells to treat type 1 diabetic mellitus in mice: an evaluation of grafted cell doses. Adv Exp Med Biol. 2018;1083:145-56.

45. Zhong $F$, Jiang $Y$. Endogenous pancreatic beta cell regeneration: a potential strategy for the recovery of beta cell deficiency in diabetes. Front Endocrinol (Lausanne). 2019;10:101.

46. van der Meulen T, Mawla AM, DiGruccio MR, Adams MW, Nies V, Dolleman S, Liu S, Ackermann AM, Caceres E, Hunter AE, et al. Virgin beta cells persist throughout life at a neogenic niche within pancreatic islets. Cell Metab. 2017;25(4):911-26 e916.

47. Ezquer F, Ezquer M, Contador D, Ricca M, Simon V, Conget P. The antidiabetic effect of mesenchymal stem cells is unrelated to their transdifferentiation potential but to their capability to restore Th1/Th2 balance and to modify the pancreatic microenvironment. Stem Cells. 2012; 30(8):1664-74.

48. Jurewicz M, Yang S, Augello A, Godwin JG, Moore RF, Azzi J, Fiorina P, Atkinson M, Sayegh MH, Abdi R. Congenic mesenchymal stem cell therapy reverses hyperglycemia in experimental type 1 diabetes. Diabetes. 2010; 59(12):3139-47.

49. Yoo SW, Chang DY, Lee HS, Kim GH, Park JS, Ryu BY, Joe EH, Lee YD, Kim SS, Suh-Kim H. Immune following suppression mesenchymal stem cell transplantation in the ischemic brain is mediated by TGF-beta. Neurobiol Dis. 2013;58:249-57.

50. Moritani M, Yoshimoto K, Wong SF, Tanaka C, Yamaoka T, Sano T, Komagata Y, Miyazaki J, Kikutani H, Itakura M. Abrogation of autoimmune diabetes in nonobese diabetic mice and protection against effector lymphocytes by transgenic paracrine TGF-beta1. J Clin Invest. 1998;102(3):499-506.

51. Mezza T, Shirakawa J, Martinez R, Hu J, Giaccari A, Kulkarni RN. Nuclear export of FoxO1 is associated with ERK signaling in beta-cells lacking insulin receptors. J Biol Chem. 2016:291(41):21485-95.

52. Asada S, Daitoku H, Matsuzaki H, Saito T, Sudo T, Mukai H, Iwashita S, Kako K, Kishi T, Kasuya Y, et al. Mitogen-activated protein kinases, Erk and p38, phosphorylate and regulate Foxo1. Cell Signal. 2007;19(3):519-27.

53. Abdallah $B M$, Ding $M$, Jensen $C H$, Ditzel N, Flyvbjerg A, Jensen $T G$, DagnaesHansen F, Gasser JA, Kassem M. DIk1/FA1 is a novel endocrine regulator of bone and fat mass and its serum level is modulated by growth hormone. Endocrinology. 2007;148(7):3111-21

54. Sul HS. Minireview: Pref-1: role in adipogenesis and mesenchymal cell fate. Mol Endocrinol. 2009;23(11):1717-25.

55. Rhee M, Lee SH, Kim JW, Ham DS, Park HS, Yang HK, Shin JY, Cho JH, Kim YB, Youn BS, et al. Preadipocyte factor 1 induces pancreatic ductal cell differentiation into insulin-producing cells. Sci Rep. 2016;6:23960.

56. Carlsson C, Tornehave D, Lindberg K, Galante P, Billestrup N, Michelsen B, Larsson LI, Nielsen JH. Growth hormone and prolactin stimulate the expression of rat preadipocyte factor- $1 /$ delta-like protein in pancreatic islets: molecular cloning and expression pattern during development and growth of the endocrine pancreas. Endocrinology. 1997;138(9):3940-8.
57. Hudak CS, Sul HS. Pref-1, a gatekeeper of adipogenesis. Front Endocrinol (Lausanne). 2013;4:79.

\section{Publisher's Note}

Springer Nature remains neutral with regard to jurisdictional claims in published maps and institutional affiliations.
Ready to submit your research? Choose BMC and benefit from:

- fast, convenient online submission

- thorough peer review by experienced researchers in your field

- rapid publication on acceptance

- support for research data, including large and complex data types

- gold Open Access which fosters wider collaboration and increased citations

- maximum visibility for your research: over $100 \mathrm{M}$ website views per year

At BMC, research is always in progress.

Learn more biomedcentral.com/submissions 